\title{
The critical invariant: Avant-garde and change
}

\section{Dr Euripides Altintzoglou,}

Course Leader (Photography), Senior Lecturer (Fine Art), Wolverhampton School

of Art, University of Wolverhampton

\begin{abstract}
'Change' is the locus of the avant-garde's revolutionary character. Historical claims and contemporary theorizations of the avant-garde enforce methodological distinctions between radical and conforming attitudes that fluctuate according to existing political agendas. This process of instrumentalization renders the avant-garde susceptible to the conformity of institutionalization. More importantly it prescribes the avant-garde with a subservient role that controls its operational means and deflates its capacity to produce politics. What is to be done, if the avant-garde achieves its goal for socio-political change? Are we to abandon the spirit of critical reflection and surrender to the conditions of the next system? How can there be an avant-garde after capitalism if its ends are solely confined in the substitution of one system with another? This article traces out this problem, assessing what kind of emancipatory potential we might expect, or hope for, from a post-capitalist avant-garde, by advancing a critical examination of recent theories of political subjectivity, the dialectics of change and the reconciliation of the institution.
\end{abstract}

\section{Keywords}

avant-garde

change

politics

radical

institutional critique

post-capitalism 
They are the guardians of the future and they are inventing the future. (Badiou 2010: 63)

Throughout modernism various avant-garde movements have subscribed to antithetical political ideologies: from the fascism of Futurism and the socialism of Constructivism, to the entrepreneurial individualism of Abstract Expressionism. More recently, historical and methodological distinctions between radical and conservative variations have identified the revolutionary character of the avant-garde as its driving force for change. In the preface to Peter Bürger's seminal work on the avant-garde Jochen Schulte-Sasse (1984: xl-xlvii) raises an important question on the fate of radical art after it achieves its would-be goal - the sublation of art into society. We can expand this concern on the ways by which the association of the avant-garde with existing specific political agendas can render it susceptible to the instrumental conformity of institutionalization, and, thus, deflate its emancipatory potential.

There have been numerous instances of resistance towards the political institutionalization of avant-garde movements. The 'Proletariat Art Manifesto' published in March 1923 fought for avantgarde autonomy. The manifesto was signed by Dada and Constructivist artists (Theo van Doesburg, Tristan Tzara, Kurt Schwitters, Jan Arp), who, although sympathetic to socialist politics, objected to the interventions of Russian and other Communist parties in cultural matters. In line with the panEuropean regress to classicism after the First World War the fascist and communist incorporation of once radical movements led to a reactionary return to tradition and ideological instrumentalization (Roberts 2015: 197). The reason why institutionalized praxis is detrimental to critical forms of cultural production is not only due to the loss of autonomy but precisely because heteronomy is susceptible to political instrumentalization. A system's survival is inherently opposed to radical change as this unavoidably involves its eventual demise. Once heteronomy substitutes autonomy, the 
avant-garde spirit of progress in the pursuit of the new is employed for sustaining a system through minor forms of corrective improvement that disguise its ideological conservatism.

On the other hand, if avant-garde movements become exclusively dedicated to specific political agendas, their potential for perpetual change risks becoming obsolete. What is to be done once a socio-political change takes place? Are we to abandon the spirit of critical reflection and surrender art's autonomy? What kind of emancipatory potential can we expect, or hope, to be advanced from a post-capitalist avant-garde? How can there be an avant-garde after capitalism, for instance, if its ends are solely confined to the supersession of this specific system? To paraphrase Marx, how can we keep changing the world? The demise of radical art (e.g. Futurism) under fascist and communist regimes has taught us that for the avant-grade to remain epistemologically viable through a constant retroactive approach to contemporary conditions it needs to sustain an open-ended research programme. Thus, it should not be solely bound in a struggle against the conditions of modernism, i.e., capital, and by extension capitalism and neo-liberalism. By perceiving the avantgarde exclusively as a response to capitalism we contain its raison d'être solely within teleological anti-capital manifestations. For the avant-garde to remain poly-political it must retain a meta-political approach. That is, in order to be for politics, the avant-garde needs to advance a critical approach on the nature of politics. This methodological distinction should not be misinterpreted as inclusive of conservative programmes but as the condition that allows for the development of existing, or the emergence of new, emancipatory programmes. In our praise for the avant-garde's political engagement, we have to understand that it alone cannot affect socio-political change. Rather, the avant-garde can be involved in change as the context that facilitates critical responses to the conditions of the present, based on the teachings of the past, for a better future.

Change is not synonymous with progress, hence why many prefer the safety and stability of the status quo. Change can also be quite a complex process that unfolds in variable degrees and ways. In most cases change is developmental and gradual, without excluding radical and transformative development. While on the one hand we can claim that all things change - in the purest of sense as 
the effect of the passage of time, movement, etc. - there are some things that do not change - the universe, the broader realities of existence. Conversely, we could argue that in fact the above distinction is false and that, in reality, everything changes but at rates and scales that might go unnoticed. This is why we also have to distinguish between subjective and objective conditions of individual and social being and existence without, however, dismissing the dialectically causal connection between the two.

In political terms when we talk about change we tend to refer to a process that affects significant transformation, which may include progressive or regressive forms. Similarly, when we refer to the new we imply the emergence of radical systems that did not exist before. Such systems are often based on previously existing ideas, or Ideas, that develop into concrete political models. This is where Alain Badiou's philosophical project on change becomes important. But instead of focusing on the contingency of the Event, I would rather problematize the phenomenology of Ideas. How, and out of which processes do Ideas emerge? To free political thinking from the metaphysics of Platonic philosophy we have to approach Ideas not just as pre-existing constants that we have merely to acknowledge and effectuate, but as the products of our socio-political responsibility. Otherwise, the conservatism of the classicist model leaves no room for the emergence of the new, cultural production (arts and philosophy). It is therefore quite obvious that this line of thought sustains the perils of hegemonic ideology; our containment within pre-existing systems renders us incapable of producing our own.

\section{An invariant drive for change}

We often dismiss the possibility of critical cultural forms of production in pre-modern societies due to the artisanal conditions of production that have produced an incredibly censored version of history of art. State, religious and ruling class control of art production through 
commissions puts in place a historical generalized exclusion of any kind of progressive, radical or challenging expressions that predate modernism and capitalism. Yet there are plenty of surviving examples of works that criticized, mocked and rejected the ideological dictates of the ruling class (Greco-Roman paintings on amphoras); appropriated religious patterns (late-Byzantine mosaics); comments on religious control of aesthetics (Renaissance rejection of medieval abstraction that advocated the spiritual aspect of being); helped emerging classes to claim their place through new forms of representation (seventeenth-century Dutch portraiture); and endorsed the critical reflection of the Enlightenment that subsequently laid the methodological foundations for the modernist avantgarde. A historicist reflection of these moments might come to consider some as conservative or at the service of what we now perceive as wrong causes. The only thing that unites them is that each one 'declared a formal break with preceding artistic schemata' (Badiou 2008a: 132), a distinction that Alain Badiou applies to all avant-garde movements of the twentieth century, but certainly not limited to the modernist timeframe. As such, we can conceive of an invariant avant-garde as a mode of critical reflection on socio-political realities and injustices.

These overarching tactics, at the service of an everlasting desire for change, lay bare the gradual emergence of avant-garde tendencies before capitalism. Another common methodological characteristic of the avant-garde is the consistent rejection of dominant cultural modes of production that are often considered traditional (Badiou 2008a: 133-35). The endurance of the avant-garde ethos is similar to Badiou's notion of a 'communist invariant' that encompasses all types of egalitarian struggle for equality:

As a pure Idea of equality, the communist hypothesis has no doubt existed since the beginnings of the state. As soon as mass action opposes state coercion in the name of egalitarian justice, rudiments or fragments of the hypothesis start to appear. Popular revolts the slaves led by Spartacus, the peasants led by Müntzer - might be identified as practical 
examples of this 'communist invariant'. With the French Revolution, the communist hypothesis then inaugurates the epoch of political modernity. (2008b: 35)

Like the invariant communist struggle, the avant-garde aims at the common good but its only unchanging logic is change. Therefore, the production of the new is perpetually open-ended and adaptable. Despite methodological similarities, the communist hypothesis aims for change based on a specific political agenda while the avant-garde sustains a drive for variable change. This change is inclusive of, but not limited to, communist ideals. To paraphrase Badiou (2010: 63), the problem will never be resolved ${ }^{1}$ because progress is sustained through a causal relationship of dealing with problems and no system is or can be perfect as that would automatically rule out the possibility of developmental progress. For Badiou the ultimate solution is located in the demise of capitalism and rise of communism. In many ways, the passionate drive for replacing capitalism with a communist alternative is forcing us to perceive the avant-garde solely as an instrument for the left, thus limiting its force for perpetual change and by extension its greater political capacity for generating new Ideas. We ought to look further than contemporaneous necessity. We need to learn from the Soviet past and acknowledge the dynamics of internal evolution that led to the demise of the state-communist project. More importantly, the dissolution of the Russian avant-garde in the state-communist project - its sublation to life - left cultural production without a critical voice that could resist the Stalinist appropriation of communism and the elimination of any alternative programme (Trotsky). No system - political, economic, artistic and otherwise - is immune to internal evolution and thus cannot guard against either its eventual demise or radical evolution. We are therefore faced with the realization that the political framework that follows a developmental process is not necessarily the last stage, despite its suitability to address a given set of invariable conditions. On the contrary, quite often there are reactionary retrogressive developments that take advantage of the need for social change and suppress progressive alternatives. 
There is a long history of egalitarian uprisings against oppressive and exploitative structures of ruling power. Many revolts advance a set of demands, but do not necessarily form concrete political agendas. In fact, such acts of resistance have the capacity to be the very events that generate revolutionary politics; violent 'nights of the world' before the dawns of new political subjectivity. ${ }^{2}$ Lenin famously spoke of the distinction between political revolutions and class struggle, which he viewed as an inherent constituent of the middle class:

For the theory of the class struggle was created not by Marx, but by the bourgeoisie before Marx, and, generally speaking, it is acceptable to the bourgeoisie. Those who recognise only the class struggle are not yet Marxists; they may be found to be still within the bounds of bourgeois thinking and bourgeois politics. (1973: 40)

Along these lines, an attempt to claim the avant-garde solely for a single agenda is a contemporary mistake, analogous to Badiou's attempt to claim all class struggle as communist. To quote Lenin (1973: 40) again: 'to confine Marxism to the doctrine of class struggle means curtailing Marxism, distorting it, reducing it to something acceptable to the bourgeoisie'. Undoubtedly, the crisis of latecapitalism is in dire need of the corrective criticisms of the left but to limit the avant-garde to a single type of struggle is to institutionalize and instrumentalize it, and thus prevent it from adapting to any other type of struggle that the future will demand. Also, as we will see further on, to reduce the avantgarde to various defensive modes of struggle is the best tactic for suppressing its true nature of producing radical alternatives.

For Badiou, an event that initiates change is contingent, 'purely hazardous, which cannot be inferred from the situation' (2005: 193). If we consider change to be a matter of 'a cast of dice' and an 'emblem of chance' (2005: 193), then radical action and critical agency are nothing more than disorganized, indeterminate forms of pacifist anticipation of political Truths that originate in external, distant and disengaged Events. Change is not a matter of metaphysics or at the service of justifying 
the righteousness of a greater cause through the adoption or imposition of pre-existing agendas. Rather, change is a continuous event occurring at variable rates and degrees of transformation. For the avant-garde to facilitate change it does not need to adopt but produce ideas pursued through adaptable methods and means. The emergence of the new requires an openness of methods, the kinds that can be found in the numerous and often disparate artistic movements. Progressive change and the new coexist in an interdependent dialectic way. Change is the ontological context within which the phenomenon of the new manifests.

Nicolas Bourriaud's notion of the 'radicant' is primarily concerned with the emergence of a model of the new that involves a concurrent eradication of the old: 'For there can be no radicality without an urgent desire for a new beginning, nor without a gesture of purification that assumes the status of a program' (2009: 46). Bourriaud resorts to botanical metaphors to advance the concept of the 'radicant', in particular to the growth of ivy. He elaborates on how radicant plants 'develop their roots as they advance, unlike the radicals, whose development is determined by their being anchored in a particular soil' (Bourriaud 2009: 51). This parallelism might be useful for clarifying a distinction between origins and destinations, but it does hide a deeper set of negative connotations of dependency that are usually associated with parasitism. What is even more problematic with such organisms is that their existence relies on host plants, buildings or structures. Such existential reliance is detrimental to disengaged autonomy. The emergence of new systems and structures becomes practically impossible as this dependency restricts the formation of the new as a path freely taken strictly within the predetermined boundaries of an existing system. The radicant and its apparent independence is, in contrast, contained in the same way that late-capitalism incorporates nonthreatening expressions of radicalism to avoid greater eruptions resulting from a total suppression of criticism.

A discussion on paths brings to mind Heraclitus' sayings on the notion of change as infinite flux - 'everything flows' - that drew its analogies from the ever-changing waters of a river. According to Bourriaud's logic a 'radical' river would only flow within its existing banks. The river waters will 
never be same at any given time but its activity will be contained within the limits of its banks. A 'radicant' river, on the other hand, would be similar to a stream embarking on its virgin voyage, setting a path and creating its own banks as it goes. While the river is an established system that accommodates change within it, the virgin stream produces change at every step of its development. Both river and stream need the context of activity: they need the earth upon which they flow. For the river its banks will become a sub-context, or a system, within the broader context of nature and earth. A virgin stream's flow, on the other hand, creates its own banks, a system within which it will grow into a river. The relationship between context and transformation is an important one for Badiou's concept of change, which, like Heraclitus' 'stream' and Bourriaud's 'radicant', is driven by an empirical phenomenology brilliantly simplified in Paulo Freire's 'we make the road by walking it' (Horton and Freire 1990).

The radical invariant might pose as an attractive model, but we need to defend ourselves against a mode of criticism that is void of any progressive intentions in relation to the avant-garde. In this respect the role of the path is important as it carries the potential of leading out of a system and, by doing so, into another. The avant-garde is not intent on simply leading us into systems already laid down for us, or to over-emphasize contained freedom as sufficient independence. The avant-garde explores the ways by which we can collectively engage with the emergence of the new and reveals how the illusion of freedom drawn from the temporary satisfaction of choice between existing options can be detrimental to the initiation of new alternatives. Navigating within existing conditions and systems keeps us in a state of defensiveness and mostly preoccupied with finding merely corrective solutions to problems. This exhausts the inventive potential of the avant-garde by deflecting attention from the source of the problem that is located in the systemic context: the banks of the river, not the flow within it.

\section{Dialectic change}


The avant-garde is driven by change, pursued through experimental and radical methods. Change can be both corrective and developmental (internal to existing conditions), and substantial (radical departure from existing structures). Badiou refers to these two types of change as 'regular' and 'singular'. Regular change is 'completely inside the laws of the world', operating in corrective ways, and singular change 'or an Event, is something like an immanent exception inside the of the world', precisely due to its radical nature (Badiou 2013: 73). The context within which change takes place is divided between objective and subjective particulars, that is, between the physicality of the world (universe and earth) and the human activity within it:

The simplest concept of the world is a collection of multiplicities with an order, and the particularity of the world is rather the particularity of the order of the order, or of the structure of the order $[\ldots]$ the definition of the world is the effect on multiplicity by the structure of the world itself. (Badiou 2013: 75)

When often we talk about changing the world we usually refer to the human conditions of existence: who we are and what we do, the ideological nature of socio-political systems and its affects.

For Badiou a 'set', in a Cantorian sense, is the context within which change takes place. A political system in not a set; rather it is the framework that regulates the set:

We must insist on the point that change is not directly a question of sets in the universe, rather it is a question of the relations between sets. Change is always a change of some relation and not a change of the set itself. There is no change of the set itself. A set is what it is and cannot change, but the relation between two differences can change. We can affirm that we can have change in a world because we have relationships between differences in a world. (Badiou 2013: 57) 
Quite often when we talk about change we confuse the world - the physical context of change - with the system or the state - our world. Of course, we should not resort to a dualist disassociation of the two. Such an inverted distinction was the greatest capitalist fraud of the twentieth century: the erroneous conjunction of world and system and the misconception that followed, that to abandon or discard the system is to destroy the whole world.

The passion for progressive change should not reduce the importance of learning from the past and accommodating certain aspects that need to remain active in the new. The 'new' should arise from a critical interrogation of historical experience and be corrective of inequalities in social and individual discrimination, ecology and humanism, capital and wealth. Although progress might seem contrary to the dominance of tradition, for Badiou 'tradition' not only has a place in the process of change but it guarantees the permanence and continuity of corrective change (2013: 6-10). In this sense, tradition is not inherently oppressive. Rather, it brings to the fore the necessity of controlling the ethical and moral dimensions of ideologies that form long-standing social frameworks. Corrective change-as-tradition aims at a generic, universal application: all humans are equal, all sexes and races are equal, etc. It is another struggle, one that attempts to preserve a continuity for the emancipatory potential of Truths that have been pushed aside by the interests of the ruling elite. But for Badiou this notion of an existing universal struggle becoming tradition is an argument solely reserved for the Truth of the 'communist invariant', which in turn is an attempt to claim all egalitarian struggle under a single political agenda: all streams and rivers leading to one sea. ${ }^{3}$

To posthumously propose that all historical struggles, without a pre-existing defined programme, belong to this or that political orientation (left/right) is to attach a teleological fate to the invariant argument. For acts of protest to produce new Ideas that can potentially develop into concrete politics - i.e. egalitarianism to communism - they need to be allowed the self-definitional space to do so. Just because we can associate certain agendas or intentions of a struggle to an existing programme does not mean that its politics should be forcibly orientated towards it. If we were to 
impose a specific agenda on protesters and rioters while they are actively engaged in a struggle, it is likely that we would influence the development of those politics within an existing ideology and thus prevent the emergence of the new. This is, in effect, instrumentalization through the back door. An egalitarian or an emancipatory invariant is not necessarily solely communist, even in the philosophical sense that Badiou is arguing. To use a historical example, this would imply that the Czechoslovakian and Polish revolts of the previous century would lead from communism to [...] communism, albeit a better version of communism. But nevertheless, what is proposed is that all struggles for emancipation should lead to this end. Rather, the 'new' should incorporate the invariant ideals of the communist tradition that historical materialism has proven to be universally in need. Similarly, the new should not exclude the ideals found in variable political programmes that are truly emancipatory. More importantly, what should not be excluded is the possibility that new ideals may emerge as we adapt to the specificities of the future. The excluded should not exclude.

Corrective change that takes place within a system should be sustained over and beyond the system that it was introduced into. Universal values such as equality, freedom and all human rights are not context-dependent needs tied to specific historical and social conditions. They are universal values that should become traditions, in Badiou's sense, to endure political and systemic changes. Conversely, corrective and developmental tactics can over-emphasize the primacy of resistance, often trapping the emergence of the new in a futile pursuit of improving the present. Nevertheless, radical and substantial change cannot emerge outside a retroactively dialectical understanding of the past and a critical engagement with the present for a better future. ${ }^{4}$ These two tactics coexist in the avantgarde's dual critical interrogation of its phenomenological context and its ontological nature. There are certain perils with both types of change. Although radical change is fundamental, it risks becoming obsolete if it is substitutive rather than perpetual. On the other hand, developmental change is responsive, with small controlled adjustments that can prolong the longevity of the present. That is, once the process of the emergence of the new has been internalized by the system certain developmental changes can potentially suppress the emergence of radical change. 
Echoes of Plato's Republic (1992) resonate in Badiou's understanding of art and science as the only disciplines that can generate Truths, given their creative and innovative agency. However, this, is only possible through disengaged forms of critical practices - an artist's studio, a scientist' lab - which reinforce Badiou's notion of Ideas generated outside of the broader context of everyday life. Bürger's (1984) model of a disengaged, isolated critical approach resembles the essential characteristics of Cartesian subjectivity. Herein seemingly lies another dialectical conflict between a model of subjectivity that has its roots in a philosophy that rejects notions of multitude and mutability, and yet is employed by avant-garde artists and theorists as a methodology for change. In fact, this methodology shares a lot more with Montaigne's reflections, in so far as they are advanced through a similar process of disengaged self-examination. In stark contrast to Descartes, Montaigne gradually recognized the inner instability of being and came to acknowledge the necessity of inherent change not only in human beings but also in all things. Unlike alienation, disengagement is voluntary and, among other things, it is a way of providing the author with a necessary critical distance. However, autonomy is causally dependent on heteronomy. We have to experience various sociocultural situations to critically reflect and act upon them.

The political and philosophical project of change is an act of negation ${ }^{5}$; thus we should accept systemic non-permanence as the only constant. Terry Eagleton identifies a very interesting paradox in relation to change and transformation. If change is radical 'it might transform the very criteria by which we could identify it, thus making it unintelligible [...] but if it is intelligible, it might be because the transformation was not radical enough' (Eagleton 2003: 246). Accordingly, if we understand the logic of a specific change then it is possible that the change is not radical enough. But on the other hand, if it is truly radical, then we would fail to comprehend it. Eagleton's strong reliance on continuity leads to certain problems: 'change must presuppose continuity - a subject to whom the alteration occurs - if we are not to be left merely with two incommensurable states: but how can such continuity be compatible with revolutionary upheaval?' (2003: 246). The problem in this view lies precisely in the understanding of change as a single-ended process with a predetermined aim. 
Continuity in change is twofold: externally it relates to the conditions that led to its manifestation and internally it is the ever-evolving mechanism that sustains its radical capacity even after $a$ change has taken place.

Slavoj Žižek offers a Hegelian solution to this problem: 'A true change sets its own standards: it can only be measured by criteria that result from it' (2012: 520, emphasis added). But, if we perceive change as a never-ending process why do we need to 'measure' it? We could measure developmental change in terms of how things develop within a system. If the project of change is free from specific agendas, why do we need to verify that change has happened or to define its radicality? Such discussions around 'measuring' and 'identifying' expose an underlying desire for controlling the process and aims of change. If we employ change for a specific end - communism for capitalism or vice versa - then, like a party or a board of directors, we are compelled to manage the process of change and its results. Yet, the emancipatory potential of radical change often involves modes of unpredictability that contradict our overbearing desire for control. Change, therefore, oscillates between an endless struggle to revolutionize the current instrumental limitations of control and equip the next stage with mechanisms of resistance against systemic conformity.

\section{Institutionalization}

It would be false to assume that tactics of institutionalization are only employed by capitalism. Italian and German variations of fascism and Soviet communism incorporated artistic and cultural radicalism in ways that served each political agenda. The avant-garde stands in existential connection to institutionalization, forcing the question of whether its radical potential would diminish in the absence of the need for resistance against conforming conditions. Recent theorizations of the Avant-Garde not only distance themselves for institutional critique but also allocate a crucial role to the institution, now perceived as an instrument for change. These forms of radicalizations of the 
institution need to remain conscious of the issues that brought about institutional critique. For instance, Marc Leger's call for the 'egalitarian transformation of institutions' (2012: 3) could still allow for institutions - both existing and emerging - to remain hegemonic if they are underwritten by aspirations of systemic control. Leger's Lacanian 'Sinthomeopathic' ${ }^{6}$ approach towards institutions risks restricting the avant-garde within a set of responsive tactics of systemic containment, despite its dialectic maturity. Similar to Leger, Gerald Raunig's 'instituent practices' are models of actions and processes that do not 'oppose the institution, but [...] flee from institutionalization and structuralization' (2009: xvii). Based on Antonio Negri's (1999) non-dialectic concept of 'constituent power' the dynamic potential of alternative 'instituting' processes and events (Raunig 2009: 173-86) does indeed provide a supportive solace and a fostering environment for 'coping and resisting today's "societies of control"" (Leger 2012: 89), which is precisely why they should contravene the teleological entrapment of hegemony. For emerging radical institutions to sustain 'the process of constitution [...] [so] that the revolution never ends' (Negri 2003: 80) they would have to resist the temptation to exhaust their transformative potential for substitutive ends, a form of instituting without constituting. As such, their capacity to '[re]compose themselves as a constituent power again and again' (Raunig 2009: 185) will not remain limited to repetitive cycles of responsive modes of resistance or types of struggle driven by defeatist aspirations for dominance, but engage in collective forms of political becoming. A critical proximity with institutions and their hegemonic nature is necessary for forming targeted modes of resistance. Conversely, institutionalization tempts the avantgarde into corrective modes, permitting minor improvements and developments to avoid radical change. In this way, ruling systems not only diffuse the opportunity for change but also employ the innovative capacity of the avant-garde to sustain their dominance through controlled and introspective development. $^{7}$

Quite often, artists dedicated to a cause are referred to as heroes. The hero is a strong figure in Platonic philosophy and likewise in Badiou's project: 
Heroism is not a negative determination, it is a rational conviction that in some circumstances, but not always, we must act on behalf of an idea and not according to our pure interests. True heroism is rational, it is not a passion without determination. (2013: 62, emphasis added)

This version of 'heroism' completely disregards the possibility of an artistic act or an Event producing a new Idea since the rejection of undetermined acts allows only for a devoted subservience to a preexisting Idea. Are political and cultural movements, thinkers and artists meant only to follow and advocate the Truths produced by pre-existing Events that originate outside such movements? Admittedly Badiou argues that artworks are Truths, ${ }^{8}$ but what could facilitate a determination in cultural forms of production towards the emergence of new Ideas?

Badiou insists on discussing change as an outcome of Events driven by a set of invariant Ideas that unite under political programmes. As such, the process of change itself cannot become an Event in its own right and produce an Idea, but rather it can only follow existing ones. This is a common position that insists that revolutionary change should follow existing concepts, leaving no room for the emergence of the new. The avant-garde is a cultural domain, a Situation, that facilitates the emergence of Events through the production of Ideas. Otherwise, autonomy is not employed in a neutral sense - necessary for the emergence of the new - but rather it becomes a manifestation of difference from the Other - the dominant framework - expressed exclusively though acts of negation. In other words, the avant-garde is reduced to a critical voice of alternative versions of existing programmes and, as such, is rendered incapable of accommodating a significant transformative ideal.

To offer just a critical corrective perspective without producing Ideas is to employ only one half of the avant-garde's potential. In his later work, Badiou considers the possibility of an Event to 'happen by change' (2013: 61), and accordingly change needs an Idea to become a possibility, for a beginning - a revolution, a riot - to affect change and not die out without any effect. Could this requirement for the adoption of an existing Idea prevent future revolts from producing politics and thus even prevent them from happening? In other words, could the need for an Idea force radical 
movements into a dilemma of either adopting an existing programme or postponing their revolutionary acts on the basis of a lack of a direction? There is an important distinction to be made here between core Ideas - such as emancipation, equality, civil rights - and political systems that are constituted by a set of such Ideas. Political systems, such as capitalism and communism, consist of some of these Ideas. A struggle can be fuelled by a core Idea, which is why it has the capacity to produce its own Truth, so that it can become an Event. When one of these Ideas affects corrective change within an existing system then we witness what Badiou calls 'tradition', when certain injustices are put right and reform the system from within. This institutionalization of the radical capacity for change, however, is precisely what diffuses the drive for a bigger change and sustains the existing system through evolutionary developments. In the realm of cultural production, the avant-garde artist becomes such a Hero, driven by an Idea (i.e., emancipation, social justice) that could certainly be part of a broader set of Ideas that constitute political programmes (communism, fascism, capitalism). Of course, Badiou is aware of this distinction, which is why, in a Platonic sense, he designates communism as an 'Idea'. What is consistently left out is the open possibility for artists to work on new Ideas through research and critical reflection. To exclude this capacity for the new is to impose a metaphysical distance between Ideas and us, albeit similar to the cosmological (Platonic) or theological (Judaeo-Christian) conceptions of our place in the world. It is precisely such a distance that allows for the manipulation of the social by hegemonic ideology: if Ideas are only to be followed, then one set can be instrumentally substituted by another to secure the dominance of a ruling system.

This transformation of Ideas into politics and the various mechanisms of institutionalization expose the avant-garde to the endangerment of internal methodological conformity as a form of immutable sets of methods and strategies. Surely, if the avant-garde aims at change, it should also be open to its own change through a constant reconstitution of its determinants. The various styles or movements that have spawned throughout early, late and postmodernism are a testament to the avantgarde's capacity to adapt to variable sociocultural conditions. However, the substitution of retroactivity with retrogression should not be misperceived as radical change. Indeed, the greatest 
threat to progress derives from the entanglement of development in the vicious circles of retrogressive substitution: from capitalism to communism and back, ${ }^{9}$ from classicism to modernist abstraction and back. ${ }^{10}$ Badiou is right to state that 'political repetition is the victory of the state $(2013: 28)$. There are many historical examples of such instances: Maurice Denis' essay 'Definition of Neo-Traditions', a spokesman for the 'Nabi' group (Pierre Bonnard, Édouard Vuillard, Félix Valloton), pleaded to avantgarde artists in the 1890 s to return to classicism. Only a few decades later and after the First World War, the French 'call to order' incorporated another return to pre-modern classicism. In politics, the collapse of the Soviet Union and subsequent broad Russian endorsement of capitalism (a tendency also evident in recent Chinese market reforms) have put in place a binary dilemma between capitalism and communism, right or left. The avant-garde needs to lead the way forward and avoid an entrapment between right and left. As Hal Foster put it: 'a postmodernism of resistance is concerned with a critical deconstruction of tradition, not a [...] pastiche of pop- or pseudo-historical forms, [it is concerned] with a critique of origin, not a return to them' (1983: xii). The avant-garde has to offer radical alternatives and not to endlessly ricochet between existing binary opposites. In this respect Bourriaud is right in arguing that 'it is a matter of replacing the question of origin with that of destination' (2009: 40).

If social change is restricted to a specific outcome (art-in-life for the left [historical avantgarde], co-optation with the market for the right [neo-avant-garde]) the avant-garde would become an instrument for imposing ideologies as opposed to resisting, correcting, redefining and facilitating the production of the Ideas that come to constitute the social domain. The avant-garde's aim should be to sustain a reciprocal relationship with socio-political frameworks: to keep changing society through art, and, art through society. In this way there would be multiple ends, each one followed by a new beginning. For instance, Blake Stimson and Gregory Sholette's (2007) advocacy of collectivism as a solution for the enhanced individualism of globalization restricts the avant-garde to a set of contemporary responses towards the current conditions of the dominant system. This type of existential reliance reconfigures the avant-garde purely as a set of corrective methods for the control 
of the present, feeding on the illusion of a move towards the future. Or, to paraphrase Rosalind Krauss (1996: 84), we need to be aware of situations where culture is preparing us for the needs of a predefined future despite the somewhat perceived critical distance from the controlled development of the dominant system.

Before the adoption and support of relational and collaborative practices by major institutions, the spatial and topological expansion of post-conceptual art allowed for the eventual institutionalization of previously excluded spaces through the curatorial assimilation of public art and its endorsement by galleries and museums. When artists occupy a non-artistic space or when independent organizations base their activities in derelict or unused buildings with a previously strong systemic identity (i.e. Unity Square HQ of Athens Bienalle) we witness the mimicking of the mechanics of institutionalization of the very system that is under critique. ${ }^{11}$ This is the exact model that the Tate Modern followed by choosing a decommissioned power station and in doing so, that moment signified the end of the 'expanded field' and openly promoted the system's capacity for diffusing radicalism through the seemingly incorporation of its critical lessons: if artists inhabit or work in neglected and impoverished urban areas, investment will follow and raise the land-value to the point that it eventually becomes prohibitively expensive for artists to live or practice.

Unlike the initiatory character of radical change, corrective and developmental strategies supervene upon and are derivative of a problematic situation. Their responsive method depends on the existence of a prior event, and therefore they manifest themselves within the confines of causal dependency. A subservient longing for acceptance or incorporation by the system is troubling in Sholette's supposition that art will eventually merge with social life once capitalism 'acknowledge[s] this missing mass [of various individual and collaborative practices operating in the periphery or outside the official economy of arts]' by putting in place a 'radical re-definition of the concept of productivity' (in Cottington 2013: 123). Under neo-liberalism the avant-garde should not set out to simply change the consumerist dynamics of the market - i.e. to replace bourgeois dealers with artistrun galleries - but to resolve the ideological pressures that diffuse the radical development of culture, 
inclusive but not limited to art production. Similarly, the avant-garde should not exhaust its critical capacities by aiming solely at capitalism or any dominant system since this would distract its attention away from the system of politics itself. As such, an overarching cultural defence against the perils of institutionalization and a return to an oscillatory autonomy will refocus the avant-garde on politics and away from system-specific solutions such as praxis and the merging of art and social life. ${ }^{12}$ Herein lies another internal contradiction, that is, for the avant-garde to 'defend' itself it needs to 'attack'. To lead a radical offensive that resists the momentary satisfaction of the reconfiguration of tradition, the avant-garde should not neglect the push towards the future by solely responding to the present.

$$
* * *
$$

Corrective or developmental tactics sustain avant-garde practices as a set of critical responses towards the mechanics of a system, but they are also in danger of limiting their radical potential within it, and, in doing so, deflecting the avant-garde from the facilitation of new politics. Such forms of avant-garde are driven by the Truths of previous Events. We should also conceive avant-garde movements and artworks as cultural Situations that accommodate the generation of Ideas in their own right for new Events to follow with the production of Truths. But for this to happen we must allow for avant-garde practices a return to their roots: a production of Ideas, or in more simplistic and perhaps familiar terms, original concepts. The attempted containment of institutionalization only allows for what is essentially an imprint, a promise of an avant-garde within the restraints of capitalism or any other dominant ideology. If on the other hand the avant-garde is solely concerned with the emergence of new politics - in the form of new relations of production - it might abandon its critical stand towards present matters. We are, therefore, faced with a fundamentally dialectic practice: the future - i.e. the emergence of the radical new - cannot emerge without a critique of the present. It is precisely because of this critique of the present that we need to guard against the attritional effects of institutional conformity that suspends radical change. The momentary 
satisfaction gained from corrective gains should not encourage a reliance on a parthenogenetic and contingent type of emergence of the new as this would be pacifist and politically irresponsible. ${ }^{13}$

This brings us back to the following question: what is to be done once capitalism or any other system is replaced by the new? The answer might not seem obvious: the avant-garde has to sustain its forms of resistance towards the hegemonic temptations of a present victory, which is necessary for facilitating the cultural conditions for the emergence of the future. But for the avant-garde to achieve this it has to also avoid the perils of repetition that exhaust its radical potential. Unlike the didactic character of institutionalized art, the avant-garde is epistemologically productive: it produces knowledge in a collaborative nexus defined and redefined by the ever-changing contextual conditions of the world. The avant-garde does not represent change to its viewers posthumously, but rather, it explores ways by which change is to be actively pursued, and as such it can produce Ideas that lead to Events: 'An event is always the opening of a new possibility. It is not the realization of a possibility but the creation of a possibility' (Badiou 2013: 28-29).

Instead of utilizing the avant-garde as another cultural context for enforcing change, we should employ it for its capacity to facilitate change. In this way the avant-garde has no end. Its main purpose is to maintain a politically responsible form of social agency against the ideological conformities of hegemonic tradition. This is why change should not be misinterpreted as a form of singular substitutive permanence or as the pursuit of the next state forever. Contrary to the agendas of specifics politics the avant-garde sustains its ideological autonomy through the multitude: an adaptive progressive stance towards variable situations and developments. Otherwise permanence is disguised as change. Change has no end. Change is perpetual.

\section{References}

Altintzoglou, E. (2016), 'Deflowered revolution: An ethical examintation of neo-liberal tactics of pacification', in E. Altintzoglou and M. Fredriksson (eds), Revolt \& Revolution: The Protester in the 21st Century, Oxford: Interdisciplinary Press, pp. 23-32. 
Badiou, A. (2005), Being and Event, London: Continuum.

(2008a), The Century, Cambridge, MA: Polity Press.

(2008b), 'The Communist Hypothesis', New Left Review, January-February, 49, pp. 29-42.

(2010), The Communist Hypothesis, London and New York: Verson Books.

(2013), The Subject of Change, New York and Dresden: Atropos Press.

Bourriaud, N. (2009), The Radicant, New York: Lukas \& Sternberg.

Bürger, P. (1984), Theory of the Avant-Garde, Minneapolis: University of Minnesota.

Cottington, D. (2013), The Avant Garde: A Very Short Introduction, Oxford: Oxford University Press.

Crow, T. (1996), Modern Art in the Common Culture, New Haven and London: Yale University Press.

Eagleton, T. (2003), Figures of Dissent, London: Verson Books.

Foster, H. (ed.) (1983), 'Post-modernism: A preface', in The Anti-Aesthetic: Essays on Postmodern Culture, Washington: Bay Press, pp. ix-xvi. 

(2002), Design and Crime (And Other Diatribes), London: Verso Books.

Horton, M. and Freire, P. (1990), We Make the Road by Walking, Philadelphia: Temple University Press.

Krauss, R. (1996), 'Welcome to the cultural revolution', October, 77, Summer, pp. 83-96.

Leger, M. (2012), Brave New Avant-Garde: Essays on Contemporary Art and Politics, Winchester and Washington: Zero Books.

Lenin, V. (1973), The State and Revolution, Peking: Foreign Language Press.

Negri, A. (1999), Insurgencies: Constituent Power and the Modern State, Minneapolis: University of Minnesota Press.

_ (2003), 'Constituent republic', in W. Bonefeld (ed.), Revolutionary Writing: Common Sense in Post-Political Politics, New York: Autonomedia, pp. 245-53.

Plato (1992), Athens: Kaktos.

Raunig, G. (ed.) (2009), 'Insituent practices no. 2: Institutional critique, consituent power, and the persistent insituting', in Art and Contemporary Critical Practice: Reinventing Institutional Critique, London: MayFly Books, pp. 173-86.

Raunig, G. and Ray, G. (eds) (2009), Art and Contemporary Critical Practice: Reinventing Insitutional Critique, London: MayFly Books. 
Roberts, J. (2015), Revolutionary Time and the Avant-Garde, London: Verso Books.

Schulte-Sasse, J. (1984), ‘A critique of Bürger's own sociopolitical pressupositions and the limitations they place on the potential of post-avant-garde', in Bürger, P. (1984), Theory of the Avant-Garde, Minneapolis: University of Minnesota Press, pp. xl-xlvii.

Stimson, B. and Sholette, G. (2007), Collectivism after Modernism: The Art of Social Imagination After 1945, Minneapolis and London: University of Minnesota Press.

Žižek, S. (2012), Less Than Nothing: Hegel and the Shadow of Dialectical Materialism, London: Verson Books.

\section{Contributor details}

Bio:

Euripides Altintzoglou explores the correlation of being, politics, and change. He is the author of Portraiture and Critical Reflections on Being (Routledge, 2018), and co-editor (with Martin Fredriksson) of Revolt and Revolution: The Protester in the 21st Century (Inter-Disciplinary Press, 2016). He currently holds the posts of Course Leader of Photography and Senior Lecturer in Fine Art at the Wolverhampton School of Art, University of Wolverhampton.

Contact:

Dr Euripides Altintzoglou, FHEA

Course Leader (Photography)

Senior Lecturer (Fine Art) 
Faculty of Arts

Wolverhampton School of Art

University of Wolverhampton

Molineux Street (MK702)

Wolverhampton, WV1 1DT

United Kingdom

T: +4401902321948

E: E.Altintzoglou@wlv.ac.uk

https://orcid.org/ 0000-0003-3091-771X

Notes

1 'But it cannot be said that the problem has been resolved: what new forms of political organisation are needed to handle political antagonisms?' (Badiou 2010: 63).

${ }^{2}$ I discuss the need for revolutions to produce their own politics in 'Deflowered revolution: An ethical examination of neo-liberal tactics of pacification' (Altintzoglou 2016: 23-32).

3 'If truth is not a generic set, a truth is only particular, a truth is only appropriate to a specific part of humanity, and so a truth is not a truth'(Badiou 2013: 16).

4 'An avant-garde group is one that decides upon a present - for the present of art has not been decided by the past, as the classicists content, but rather hampered by it' (Badiou 2008a: 135). 5 'A change is negation. We cannot think change without claiming that something is not as it was before' (Badiou 2013: 38). 
${ }^{6}$ Leger defines the 'Sinthomeopathic activity' as 'lending oneself to institutional arrangements, the symptoms of contemporary cultural production, while still maintaining the fantasy of critical distance' (2012: 99). For Leger's thorough account of the Lacanian 'Sinthomeopathic' model see 'Welcome to the cultural goodwill revolution: On class composition in the age of classes struggle' (2012: 82-99).

${ }^{7}$ Thomas Crow talks of how the neo-avant-garde has been subsumed by capitalism by becoming the 'research and development arm [...] of the culture industry' (1996: 35).

8 'Aesthetics is the name of the relationship between philosophy, art, and history. And so it is not a creation of truth because it is the work of art itself which is the creation of truth' (Badiou 2013: 67). 9 'The (19th-century) movement and the (20th-century) party were specific modes of the communist hypothesis; it is no longer possible to return to them. Instead, after the negative experiences of the 'socialist' states and the ambiguous lessons of the Cultural Revolution and May 68, our task is to bring the communist hypothesis into existence in another mode, to help it emerge within new forms of political experience. This is why our work is so complicated, so experimental' (Badiou 2010: 37, emphasis added).

10 Thomas Crow talks of how art history repeated itself in modernism: 'Yes, it has to be conceded, low-cultural forms are time and again called upon to displace and estrange the deadening givens of accepted practice and residuum of these forms is visible in many works of modernist art' (1996: 4).

${ }^{11}$ For a discussion around the similarities between contemporary art and neo-liberalism 'pluralism', 'pragmatism' and 'relativism' see Hal Foster, 'The funeral is for the wrong corpse' (2002: 123-43).

12 The Greek origins of 'praxis' indicate simplistic forms of 'making', which suggests that production is subject to the commands of a commissioner with a specific agenda, and 'politics' is a responsible form of being within organized social structures expressed through creative autonomy. ${ }^{13}$ Similarly, Adorno forces radicalism in a state of hibernation by waiting for change and not initiating it (Schulte-Sasse 1984: xlii). 